\title{
An Action-oriented Critical Pedagogical Theory
}

\author{
Robert FitzSimmons \\ Language Centre, University of Lapland \\ PO Box 122, 96101 Rovaniemi, Finland \\ E-mail: Robert.FitzSimmons@ulapland.fi \\ Satu Uusiautti \\ Faculty of Education, University of Lapland \\ PO Box 122, 96101 Rovaniemi, Finland \\ E-mail: satu@uusiautti.fi
}

Juha Suoranta

School of Social Sciences and Humanities, University of Tampere

33014 University of Tampere, Finland

E-mail: Juha.Suoranta@uta.fi

Received: Feb. 1, 2013 Accepted: March 21, 2013 Published: May 1, 2013

doi:10.5296/jse.v3i2.3203ＵRL: http://dx.doi.org/10.5296/jse.v3i2.3203

\begin{abstract}
In this study, critical pedagogy is put into active practice by offering insights for teachers and educators in applying an everyday pedagogy of the heart for classroom involvement. The themes of breaking through the cynicism and discovering the art of deliberation are discussed especially in the Finnish context. As a conclusion, it is being suggested that education needs to refocus itself on concern and commitment for the other in our lives. Combining love with an ideological background, such as critical pedagogy, provides a new addition to the discussion.
\end{abstract}

Keywords: Critical pedagogy, Revolutionary pedagogy, Pedagogy of the heart, Art of deliberation, Pedagogical love 


\section{Introduction}

In Finland, education has been considered the means of distinguishing itself as its own democratic nation with a strong moral commitment to the welfare of the whole nation. (Anttonen, 1998; Paksuniemi, Uusiautti, \& Määttä, 2012). According to the founders of the Finnish elementary school, education was to be seen as a tool for maintaining national identity, literacy, and political freedom (e.g., Cygnaeus 1910). In the 1960s, the educational system in Finland was reevaluated following the ideology of equality of educational opportunities, producing, for instance, comprehensive school systems and a considerable increase in the number and availability of institutions of higher education (Kivinen, Ahola, \& Hedman, 2001). At the end of the 1980s, educational administration was decentralized in the Finnish society to improve the quality of education by increasing flexibility and by introducing new evaluation mechanisms. In all, the Finnish education policy has repeated the strong belief in social progress through the continuous development of education (see Rinne, Kivirauma, \& Simola, 2002). In today's Finland, education is a public service, and general education, vocational education, and higher education are free of charge (Jakku-Sihvonen \& Niemi, 2006).

According to Webb et al. (2004), constructivist theories of learning have led Finland to move away from centrally prescribed national curricula toward the development of school-based curricula with active learning pedagogies resulting in changing roles and responsibilities for teachers (Webb et al., 2004). In 1971, the teacher training law transferred teacher training to Finnish universities. Ever since that, Finnish teachers receive research-based education as teachers’ work was regarded as constant research (Jakku-Sihvonen \& Niemi, 2006).

High-quality teacher training has been named one of the core reasons for Finland's success in, for example, the Programme for International Student Assessment (PISA) (Lavonen \& Laaksonen, 2009; Välijärvi et al., 2007). On the other hand, for example, in the international comparison of Trends in International Mathematics and Science Study (TIMMS), Finnish success was also explained by the overall high appreciation of studying: Finnish pupils have books and other study equipment (e.g. internet access) at home which was clearly connected with high study results (Kupari et al., 2000).

However, what has been ignored is the fact that the joy of learning vanishes early on during the pupils’ learning life (see Helsinki Times 10-16 January 2013). In other words, Finnish students do not thrive at school: the atmosphere at school has proven lower than in average in OECD countries and students have a negative attitude toward school (e.g., Kämppi et al., 2012). In addition, although they know how the society works, and their knowledge of civics is good in international comparison, their willingness to political participation is lower than in other OECD countries (see Kupari \& Siisiäinen, 2012). Simultaneously, more and more expressions of violence and malaise take place in schools and youth camps (Elovainio et al., 2011; see also Horsthemke, 2009; Kaltiala-Heino et al., 1999). The tendency is worrying.

During the 1990's Finland experienced a deep recession resulting in massive firings and layoffs. Also, with the fall of the Soviet Union in 1991 Finland had to rethink its trade policy and also its relationship with the rest of Europe and also its domestic policy. A sea change 
was implanted by successive right-wing governments to bring Finland out of the recession and into the twenty-first century and this sea change in policy had a direct impact on the Finnish Nordic Welfare State. Finland joined the European Union in 1995 and with it the policy makers began to lead education away from its established foundation of social justice and social equality and into a more market driven educational system based on efficiency and results (see Rinne, 2000). As Rinne (2000) has also pointed out the trend in education was limited to "all kinds of competitiveness and an increasingly unequal division of resources" (p. 135). By 1999, the Nordic model of education that was developed in Finland was at death's door and as Finland entered the twenty-first century, educational policy shifted away from a government sponsored equal education for all to a more deregulated, decentralized, and market oriented educational policy (Rinne, 2000). This new market-driven capitalist direction in education both for the youth and for adults has led to vast inequalities in Education policy and along with it, a creation of a new class of marginalized youth and adults, something that was unheard of and unseen during the old Nordic model of education.

Among the problems of the current capitalist orders of education is that success is seen as the only indicator that matters and that the ideologies that lie behind our action are not recognized or reflected by teachers and therefore not by students sufficiently. In this article, we will discuss how critical pedagogies are needed to challenge the assumptions, practices, and outcomes taken for granted in conventional education (Burbules \& Berk, 1999; Gruenewald, 2003). The review is based on Dr. Robert FitzSimmons doctoral research and the analysis was expanded in collaboration with Prof. Juha Suoranta and Dr. Satu Uusiautti. We are aiming at critical thinking that not only brings teachers and students into a dialogue but also questions the very conditions of that dialogue. Thus we need a critical pedagogy that emphasizes capitalist social relations and their consequences in school life (McLaren, 2010). Critical pedagogy could be put into active practice by offering insights for teachers and educators in applying an everyday pedagogy of the heart for classroom involvement (Freire, 1998). We will analyze the use of deliberative classroom as a means of realizing critical pedagogy. Consequently, it seems that there is need to discuss its practical side as well (e.g., Buckingham, 1988; Howard, 2003): an action-oriented critical pedagogical theory.

\section{Breaking through the Cynicism}

We live in a world that can seem cynical. Freire (1998) commented that faith is needed so change can occur. But it is not only the abused that need such a faith but also teachers and educators and the students they teach. According to Freire (1998), faith is not easy to possess because faith places demands on those who have faith. To have faith "demands a stand for freedom, which implies respect for the freedom of others, in an ethical sense, in the sense of humility, coherence, and tolerance” (Freire, 1998, p. 105). But to have faith also implies a proactive orientation for liberation and an "engagement in a struggle for it. It is as if the fight against exploitation, its motivation and the refusal of resignation were paths to salvation" (Freire 1998, p. 105). And liberation is the ability to fight against individual and collective oppression which are experienced daily in the life-world. In part, liberation and faith take on a hope mentality. And for Freire (1998), hope comes when "educators (...) analyze the comings and goings of social reality (p. 107)”. 
Although the process of getting students into their own collective social reality in practice can be daunting because for many students, the analysis of social reality can be a threatening endeavor as students seek answers to the oppressions that they may have been unknowingly experiencing. But also, the analysis takes on a much more broader perspective as issues such as domestic violence, marginalization, unemployment, poverty, alienation, alcoholism, health care, inequality, disparities in schooling practices, malnutrition among the elderly and a host of other social issues that may come up for critical problem-solving in the classroom. For us educators in Finland, it is not important that Finland may be number one in math or science in PISA rankings but rather that we have a student body that walks through life with "eyes wide open" -eyes that are not only engaged with their community but also with eyes that are keen on observing the oppressive nature of their own realities; and that students are able to find their voice in the classroom and in the community.

We are calling for a Finnish education system that brings the student into her common human heritage so that she can exist within her common humanity not in silence but in the active usage of language (see also Harnecker, 2010). Hence, what becomes important is the breaking of human silence. We refer to the silence of the individual as they attempt to navigate life currents and also the inability of people to stand up for themselves and speak out against oppression. Radical pedagogy needs to find a way to educate individuals to actively voice their opinions and challenge what is oppressing them. And this does not entail just discovering a pedagogy but also a strategy for intervention. The classroom is one area where students can learn the skills needed for altering society norms if these norms are counterproductive toward human development and voice engagement.

As a pedagogical theory, radical pedagogy seeks to allow students to overcome the pedagogy of silence (see e.g., Ellsworth, 1989) and with it, apathy. Zembylas and Michaelides (2004) have analyzed silence from a positive perspective. They claim that "the focus should be on how silence works rather than what it means, the issue for the teacher is to identify how silences work in the public context of the classroom” (Zembylas \& Michaelides, 2004, p. 203). However, the silence which we refer to is the pedagogy that does not allow students to have voice in the classroom or in their community. The pedagogy of silence is related to the concept that all is well when actually all is not well. The dialectical relationship between the pedagogy of silence and a genuine pedagogy of active engagement is a bipolar one, where students can feel frustrated when their voice is not heard or required (cf., Delpit, 1988). In this case, silence takes on many forms. On the one hand, students want to discover their voice and yet, feel staimed in doing so because the teacher makes no room for voice. And yet, in other cases students feel oppressed and sense that having a voice is useless because no one listens or that it is useless to speak out and be heard.

The ability to step outside the circle of conformity is not simple nor is it easy. Radical educators will need to tread carefully: Students can be very much aware of experiencing contempt or censure by their peers and certainly the fear of being judged harshly by a peer is very much a part of a student's thought process (e.g., Hallinan \& Williams, 1990). For Lorde (1984), the solution may be found in more critical visibility. 
For individuals to break the pedagogy of silence they must discover a pedagogy of critical visibility which refers to a visibility where students can learn and practice the fundamental skills necessary for critical citizenship in the classroom. How can we begin to create a pedagogy of critical visibility as teachers, educators and concerned individuals?

The Finnish society is in the process of cultural change toward multiculturalism and this change will not just reflect on the school but also on the community and workplace. Communities and schools are not just places of being and learning. They are places of human gathering where human beings come together in interaction as social beings. Schools have also been compared to "crossroads, marketplaces, village squares, and cities themselves" (Parker, 1997, p. 18) and as such they are mirrors reflecting our outer communities. When we take this into consideration, we will need to begin to focus on a pedagogy that can enhance a student's sense of concern and commitment for the greater good of all living organisms on the planet. For this to happen, education needs to concentrate less on a "pedagogy for survivalism" and more towards a pedagogy for humanity. Tyack has claimed that education can "betray a survivalist style of thinking" where the human being is regulated to "human capital” (Tyack, 1997, pp. 22-23). We can see such a pedagogy of survivalism in Finland as students are being prepped for the workplaces of the future. However, we see a need to challenge this survivalist approach to learning. One way (but not the only way) we see that this can be achieved by teachers and educators is through a deliberative arts classroom.

\section{Discovering the Art of Deliberation}

Critical pedagogy is a pedagogy which challenges a market-centered schooling policy (McLaren, 1998). The pedagogy is also an action-centered pedagogy that confronts a market-centered education. According to Mander, the life-world "has advanced to a capitalist utopia: a giant, nonstop global marketplace that carries itself into all experiences” and this also would include education. Mander also claims that "corporations have been like a 'community' for us” where we mourn the passing of corporate leaders as if they were members of the family (Mander, 2012, p. 19).

We see the benefits of a classroom which focuses attention on deliberation where knowledge can take on a "social character" where cooperation in the classroom becomes the norm to maximize understandings of human actions and their possible consequences and to give "a basis for questioning the values and mechanisms of the dominant capitalist order" (see McLaren, 1998, p. 439). Finland is no exception to the corporate infiltration of how and why knowledge is produced and to the process of the globalization of knowledge and capital.

Accordingly, an art of deliberation can be one way in which students begin to face real life issues with respect and dignity in the classroom. But what exactly is a deliberate art classroom and how it is connected with critical pedagogy? Parker has given us a wonderful definition:

Deliberative Arts comprises of “a host of skills": learning as well as talking, taking turns, striving to understand points of view different from one's own, criticizing ideas rather than persons, admitting ignorance, slowing the rush to judgment so as to reframe the 
problem or gather more information, courageously asserting unpopular views, supporting claims with reasoning, drawing analogies, and appreciating Voltaire's principle: "I disapprove of what you say, but I will defend to the death your right to say it." (Parker, 1997, p. 20)

There is much to reflect on in Parker's definition for educators and teachers as well as for educational researchers who want to follow the ideology of action-oriented critical pedagogy. A deliberative arts classroom is a way of doing teaching with explicit goals for students to accomplish. And in its own way, puts the work of Freire into an active mode of classroom practice. Furthermore, as students learn how to deliberate together for better understanding of the other, there comes a sense of comprehending the other through dialogue and questioning because deliberation requires a thoughtful analysis of differing opinions. As Parker stated, deliberation is not only a means of advancing points of view but also it is about having the courage to promote ideas that may not be popular at the moment and developing the understanding that ideas may be criticized with no personal intent. Also, within deliberative arts, the students can reshape their own views with the realization that learning is a cooperative endeavor between human beings and not a lone ranger exercise (Parker, 1997).

Examples of this kind of classroom should be found throughout the student curriculum with teacher support and implementation. Students can discuss bigotry, racism, and prejudice and how humans can hate without justification or hate through populist rhetoric. In addition, questions can be asked about human nature and the conditions which would allow human beings to treat other human beings cruelly. Students can also learn about the Great Depression and draw comparisons from their own modern time frame. Questions about losing a job, going without food, feelings of insecurity, feelings of powerless, and marginalization can be discussed thoroughly with modern day examples between students as well as local issues both within the school and within their community by drawing up a list of concerns with the aim of problem solving.

The point behind such a classroom would be for the students to express themselves without fear with the understanding that diverse viewpoints enhance critical life and not hinders it. Of course, we acknowledge that these are delicate and difficult sometimes even impossible issues to deal with in the classroom. These questions demand safe social conditions in the classroom and trustful atmosphere between students and between them and their teachers. What becomes important is that such issues and problems are discussed carefully and reflectively. Moreover, students will need to do group preparation for the deliberative process to succeed (Paley, 1992).

The group perspective is important for doing life because students learn to work together as co-equals in the learning process. But it is also a way for students to learn from their peers through constructive criticism, listening and engagement as opinions and viewpoints are shared between the group: all skills needed for the "real" public arena that lives outside the classroom (Parker, 1997). The importance is placed on independent critical thinking or on the individual being able to think for themselves without interference from intellectuals or political leaders. What becomes important in this type of classroom is the discussion/dialogue 
emphasis; discussion in the sense that students can see how other students think and articulate their thoughts. There can be disagreement and agreement and a sharing of insights within the classroom (Allman, 2001).

According to Lim (2011), the nature of democratic deliberation does not simply center on what is epistemically correct, but rather, and more crucially, what is socially just and morally right-following the principles of critical pedagogy. Individuals can both deliberate over issues of social justice and moral goodness and come to think of themselves in ways that fundamentally tie them to other members of society. Lim (2011) continues that "an education in critical thinking is the only education of which it can be truly said prepares the individual for democratic participation” (p. 784). In all, McMillan and Harrigen (2002) encourage teaching deliberation among students: according to them, the available empirical evidence concerning teaching deliberation is sparse, but promising. Likewise, Gastill (2000) claims that deliberation can boost sense of political efficacy and even spur greater political engagement.

What role does critical pedagogy play in the lives of the mainstream of any given community? To answer this question we will need to focus on civic society and its role in implementing change. Civic society when it is focused on democratic change and when individuals can band together to work for what they consider to be the common good, can be a driving force for meaningful social transformation (Harnecker, 2010). Teachers and educators need to encourage this vision within their classroom. Furthermore, one goal behind critical pedagogy is to untie local involvement both on the local and global level because it is this involvement that can bring an organic grassroots democracy to fruition and this is also why a radical pedagogy exists: to help people to believe in social change and in what role we, the people, can play in forwarding our beliefs, desires, and aims to the elite who at times seem oblivious to our existence. For this untying to happen, individuals will need to be involved in civic education (see Tyack, 1997).

\section{Civic Responsibility as a Part of Action-Oriented Critical Pedagogy}

Tyack stated that civic responsibility was being pitted away through apathy. And for Tyack, there needs to be more democracy in education. Accordingly Tyack (1997) states: "Students learn democracy not only in classrooms but also by observing democratic processes in the adult world” (p. 22). In addition, we agree with Roine (2010), a senior technology advisor, when he stated: "With a growing world population, diminishing global resources, predicted climate change and a shake-up of the global economy, perhaps the time is right to rethink every aspect of how we live our lives” (p. 2). Roine makes it clear that human beings need consistently to rethink their own ideologies on how to do life but he also stresses the need for individuals to search out the "best ideas and concepts" to impact the global community. His manifesto has a positive ending for the planet if we can begin to openly deliberate and revise some of our own preconceived ideas and points of view about how this planet should be governed and managed. As Roine (2010) states in his conclusion:

We can make this world a better place for everybody while simultaneously maintaining the beauty and biodiversity of our planet. However, we need a dynamic revision and 
development of the whole of society using "best available" principle and practices. (p. 2)

For a more critically engaged learning experience the rethink, the redoing, and the remaking of our local and global worlds become a paramount importance as a learning activity experience, if the critical engagement of ideas will be on the agenda.

We also believe that education will need to focus on at least three tenets to help students and adults cope with changing life circumstances. The first tenet is the active use of the verb to reflect. Reflection needs to become an integral part of the curriculum because it allows students to digest the information learned. Furthermore, reflection allows for a careful consideration of the subject matter so that students can critically engage ideas that directly influence their life-world. The second tenet is the active implementation of the verb to speak. Students and non-students alike will need to learn to dialogue about the human condition during this current moment of capitalist degradation that we see fermenting all around us. Through active speaking, dialogue or deliberation, we can exchange the jelly fish for something more powerful and strong. The third tenet is the powerful verb to act. It is within this third tenet that true change can occur because the human being is in full movement for social transformation after careful reflection and deliberation about issues that directly impact their lives. Within the notion of to act, is the realization that we are not alone but rather we have countless brothers and sisters who are experiencing the same plight and who desire to see various oppressions disappear from their life-world (see FitzSimmons, 2004).

But what do these tenets mean in practice for the Finnish education curriculum? Perhaps the answer can be found in the following examples (see FitzSimmons, 2004): The ideology of action-oriented critical pedagogy could be implemented already during the entrance into higher education. The testing procedures could also give students opportunities to deliberate, debate, form learning unions and circles (see e.g., McClelland, 1973; Stringer, 2008).

Learning can become a shock and awe experience as students learn to embrace the notions of "formal" and "authentic" freedom with the understanding that authenticity comes from within as they find their voice in the classroom and in society. Thus, learning should be not be bound to auditoriums and teacher-led and textbook-based pedagogies-for example, Catherine Fallona (2000) suggests that rather than giving university teachers "a bag of tricks", teacher-education programs should encourage future teachers to understand teaching from a wider perspective. Of course, this is only a partial list of learning possibilities and we hope that the list can be enlarged by teacher educators when students and adults not only enter the classroom but also when they practice life but also do life in everyday life situations.

Cornell West argues that young people are immersed in a media world that creates a "distractive amusement and saturates them with pleasurable sedatives that steer them away from engagement with issues of peace and justice”. Furthermore, this media "also leaves them ill-equipped to deal with the spiritual malnutrition that awaits them after their endless pursuit of pleasure" (West, 2004, pp. 174-175). We need to consider carefully what West wrote. Certainly the media takes us further away from social reality engagement. However, critical educators can use the situation for critical analysis and reflection by offering a 
deliberative classroom where students can actively engage the media message through dialogue and by asking challenging questions about the ideological intent of such media practices.

Educators will also need to critically analyze the role of capital in students' lives and offer possible alternatives to capital development for students to deliberate in a democratic classroom. Moreover, teachers and educators will need to come to the realization that learning institutions serve the values of capital in disregard of the social. Without the consideration of a new ideology, we will find that dialoging about a meaningful transformation could be made meaningless. We bring this up for consideration because of its importance in challenging the dominant ideology that we are now living in and the role that schooling plays in reproducing capital. We are guided by the Marxist dictum that our society needs to be open to ruthless critique if an authentic possibility for change is to succeed. And we also understand that critical education needs to be located in the real and living social entity of life with a central focus on what can contribute to the common good of all species on our planet.

\section{Education: A Means for Achieving Ends or an End Itself}

We believe that there are two views of education at play inside a critical pedagogy. On one hand there is a notion that education is only a means or an instrument for achieving desired ends relative to the given politico-economic power balance or economic system: capitalism. On the other hand, there is another way to look at this question based on the idea of autonomy of education, or education as an end itself. This is a humanist vision of education which is against all ideologues except the common good, the good of human beings and the positives in human nature. Of course, this view of education is fragile and even idealistic and romantic, but, yet again, it has lasted the test of time. Accordingly, critical educators need to somehow decide whether to keep education as a technical part of the mechanisms of political power, or, perhaps, think and practice it as something more precious, more valuable from the point of view of human dignitas and human habitus.

Thus we can, or perhaps, we must try to merge the two views into one thereby creating a more just and humane socio-economic system through schooling and educational practice. But how to do it? We are inclined to think as Michael Hardt and Antonio Negri, who, among others, emphasize education as commons. In order to make education as an institution of the common, we must have educational "resources common, develop schemes of self-management, and subject all decisions to procedures of democratic participation” (Hardt \& Negri, 2012, p. 41). In practice these ideas mean, firstly, that we must foster open access and open platforms for education, that is, we need to link old ideas of Nordic folk education with new open digital resources. Secondly, we need to emphasize pedagogy and pedagogical models, which strengthen peoples' self-awareness as capable learners. Self-education is needed but also new forms of shared learning and mass education in the digital realm (cf. Wikipedia). Thirdly, as Hardt and Negri (2012) state, nowadays there is too much top-down decision making in the schooling system: "Democratic decision making structures must replace the present forms of planning that determine the development of education” (p. 42). 
In addition, we fully agree with McLaren (2010) about the need for a larger social position outside the capitalist-value paradigm. However, we need to see other perspectives that may also combat the influence of capitalist social relations and look for new ways to struggle against the capitalist dominated educational machine. Critical pedagogy should seek to give that personal responsibility to the students and to other members of the community through a collective awareness of the other. And in doing so, the goal is to replace capitalist schooling with a learning practice that focuses on the human being's personal wellbeing so that the public arena of life becomes a socially humane enterprise.

The point is that the whole ideology of schooling and pedagogy should be changed. Students need to have agency, they need to feel that they are official partners and participants of their school. In addition they need a group proper that is a small learning community around them to negotiate and share ideas freely. They need access to computers or other digital tools to communicate with each other and with larger society and the world (Mitra \& Dangwal, 2010). In a deliberative arts classroom, students can engage in meaningful dialogue and conversation about the knowledge being learned. Such a classroom stays away from what Freire has termed "lifeless and petrified" (Freire, 1988, p. 57) and moves the classroom into a more transformative and liberatory practice.

\section{Conclusion: Concern and Commitment for the Human Essence}

The tendency is worrying: Simola (2004) is afraid that we might move from our traditional pedagogy to the new pedagogy of categorizing and classifying competition including the ideology of pervasive evaluations and self-assessments. He continues that we need research that can identify the possibilities, forms, and spaces of freedom that elucidates the realistic Utopian and provides strength to resistance through dissecting education within the society and analyzing the relationship between education and the political, social, cultural, and economical world (Simola, 2004).

As argued in the beginning of the essay, what is missing in Finnish education is the lack of care element. We argue that the love of neighbor - even the stranger among us - becomes a central focus for educational planning, if we wish to subvert the market materialism that educational policy is now engaged in within the Finnish curriculum. As we understand critical pedagogy, the pedagogy is centered in fortitude, perseverance, and hope. Furthermore, the pedagogy is cemented in resistance but a resistance that is peaceful and productive for implementing change in the species community when and where change is necessary to create a holistic life-world. But more importantly, the pedagogy is about love. Ernesto "Che" Guevara stated (1965):

At the risk of seeming ridiculous, let me say that the true revolutionary is guided by great feelings of love. It is impossible to think of a genuine revolutionary lacking this quality... Our vanguard revolutionaries must idealize this love of the people, of the most sacred causes, and make it one and indivisible. They cannot descend, with small doses of daily affection, to the level where ordinary people put their love into practice.

As Ernesto "Che" Guevara stated a true revolutionary has love for humanity and we believe 
that it is this love of humanity that carries the pedagogy forward. And this forward movement is not about exclaiming only the negative within any given society but about proclaiming the positive within us all.

The idea that education only needs to prepare the student for exams and working life needs to be questioned and challenged. No longer can we accept the human tragedies that are spawned from such a pedagogy of silence that encourages passivity and lack of resistance to the status quo. Critical pedagogy puts the absurdity of the capitalist system and its current ideological dominance on the table for deliberative discussion. And it takes this discussion through a critical assessment of questions and dialogue inside a classroom setting. Critical pedagogy seeks out public engagement by cutting through the capitalist hegemony that confronts students in everyday practice by offering an interactive and deliberative arts classroom so that students can actively engage the world through critical knowledge and observation. And its endgame is centered in the future by offering the learner a vision of hope, a hope "rooted in children's passionate belief in fairness" and "in their willingness to discipline themselves to create just solutions to problems” (Wilkerson, 2011, p. 393).

Keith (2010) argues that educators can join the struggle by searching for ways to conceptualize and construct classrooms that include and promote equity and justice for students who are poor and members of racial, ethnic, and other socially constructed minorities. Keith refers to the power of love in this struggle. Instead of defining teacher quality only in terms of subject-matter knowledge, pedagogical reflection should be oriented toward understanding the significance of pedagogical events and their relations to children and their lifeworld through a pedagogy of love (see Saevi \& Eilifsen, 2008). The question is about the combination of teachers' pedagogical love and authority (Määttä \& Uusiautti, 2012).

In a formal comparison the Finnish schooling system seems to be unparalleled, but from the point of view of critical pedagogy we have emphasized in this text, it sometimes lacks not only the spirit and joy of learning but also an atmosphere of mutual care and pedagogical love. Through love, the teacher has the power to practice critical pedagogy in a way that not only ignites students' critical thinking but also makes them develop in a caring educational environment. We firmly believe that it is now time to act and bring the classroom into a new life affirming shock and awe learning experience, a learning possibility that would bring an organic whole to the classroom and bring education into a more human-centered life affirmation. For critical pedagogy, the ability to critically reflect and interpret the world is not sufficient, one must also be willing and able to act to change that world (Burbules \& Berk, 1999). Pedagogical love with a good ideological direction can be a great addition to the discussion. But without ideology in the background such as critical pedagogy, love may become just a word without action.

\section{References}

Allman, P. (2001). Revolutionary social transformations: democratic hopes, political possibilities and critical education. Westport and London: Bergin and Garvey. 
Anttonen, A. (1998). Vocabularies of citizenship and gender: Finland. Critical Social Policy August, 18, 355-373. http://dx.doi.org/10.1177/026101839801805605

Buckingham, D. (1988). Critical pedagogy and media education: a theory in search of a practice. Journal of curriculum Studies, 28(6), 627-650.

Burbules, N. C., \& Berk, B. (1999). Critical thinking and critical pedagogy: relations, differences, and limits. In T. S. Popkewitz \& L. Fendler (Eds.), Critical theories in education. New York, NY: Routledge.

Cygnaeus, U. (1910). Uno Cygnaeuksen kirjoitukset Suomen kansakoulun perustamisesta ja järjestämisestä [Uno Cygnaeus's writings about the establishment and organization of Finnish elementary school]. Helsinki: Raittiuskansan kirjapaino.

Delpit, L. D. (1988). The silenced dialogue: power and pedagogy in educating other people's children. Harvard Educational Review, 58(3), 280-298.

Ellsworth, E. (1989). Why doesn't this feel empowering? Working through the repressive myths of critical pedagogy. Harvard Educational Review, 59(3), 297-324.

Elovainio, M., Pietikäinen, M., Luopa, P., Kivimäki, M., Ferrie, J. E., Jokela, J., Suominen, S., Vahtera, J., \& Virtanen, M. (2011). Organizational justice at school and its associations with pupils' psychosocial school environment, health, and wellbeing. Social Science \& Medicine, 73(12), 1675-1682.

Fallona, C. (2000). Manner in teaching: A study in observing and interpreting teachers' moral virtues. Teaching and Teacher Education, 16, 681-695.

FitzSimmons, R. (2004). Toward a critical revolutionary pedagogy: Inquiries into Karl Marx, Vladimir Lenin, Mao Tse-Tung and Fidel Castro. (PhD Diss., Acta Universitatis Lapponiensis, no. 71, University of Lapland, Finland).

Freire, P. (1988). Pedagogy of the oppressed. New York, NY: Continuum.

Freire, P. (1998). Pedagogy of the heart. New York, NY: Continuum.

Gastil, J. (2000). Is face-to-face citizen deliberation a luxury or a necessity? Political Communication, 17(4), 357-361. http://dx.doi.org/10.1080/10584600050178960

Gruenewald, D. A. (2003). The best of both worlds: a critical pedagogy of place. Educational Researcher, 32(4), 3-12.

Guevara, E. (1965). Socialism and man in Cuba. The Che Reader. (Originally published in March 12, 1965, under the title From Algiers, for Marcha, The Cuban Revolution Today.) http://www.marxists.org/archive/guevara/1965/03/man-socialism.htm

Hallinan, M. T., \& Williams, R. A. (1990). Students' characteristics and the peer-influence process. Sociology of Education, 63, 122-132.

Hardt, M., \& Negri, A. (2012). Declaration. New York, NY: Argo Navis Author Services. 
Harnecker, M. (2010). Latin America and twenty-first century socialism, inventing to avoid mistakes. Monthly Review, 62(3), 1-78.

Helsinki Times. Finnish pupils top of the class but have no love of schooling. January 2013, 10-16

Horsthemke, K. (2009). Rethinking humane education. Ethics and Education, 4(2), 201-214.

Howard, T. C. (2003). Culturally relevant pedagogy: ingredients for critical teacher reflection. Theory Into Practice, 42(3), 195-202. http://dx.doi.org/10.1207/s15430421tip4203_5

Jakku-Sihvonen, R., \& Niemi, H. (2006). Introduction to the Finnish education system and teachers' work. In R. Jakku-Sihvonen \& H. Niemi (Eds.), Research-based teacher education in Finland - reflections by Finnish teacher educators (pp. 7-16). Turku: Finnish Educational Research Association.

Kaltiala-Heino, R., Rimpelä, M., Marttunen, M., Rimpelä, A., \& Rantanen, P. (1999). Bullying, depression, and suicidal ideation in Finnish adolescents: school survey. British Medical Journal, 319, 348-351.

Kämppi, K., Välimaa, R., Ojala, K., Tynjälä, J., Haapasalo, I., Villberg, J., \& Kannas, L. (2012). Koulukokemusten kansainvälistä vertailua 2010 sekä muutokset Suomessa ja Pohjoismaissa 1994-2010 - who-koululaistutkimus (HBSC-study) [International comparison of school experiences 2010 and changes in Finland and Nordic Countries in 1994-2010 WHO student research (HBSC-study)]. Helsinki: National Board of Education of Finland.

Keith, N. (2010). Getting beyond anaemic love: from the pedagogy of cordial relations to a pedagogy for difference. Journal of Curriculum Studies, 42(4), 539-572.

Kivinen, O., Ahola, S., \& Hedman, J. (2001). Expanding education and improving odds? Participation in higher education in Finland in the 1980s and 1990s. Acta Sociologica, 44, 171-181.

Kupari, P., Reinikainen, P., Nevanpää, T., \& Törnroos, J. (2000). Matematiikan ja luonnontieteiden osaaminen peruskoulussa [Pupil achievement in math and science in basic education]. Jyväskylä: Finnish Institute for Educational Research.

Kupari, P., \& Siisiäinen, M. (2012). Kodista ja kiinnostuksesta se lähtee. Suomalaisnuorten kansalaispätevyys ja yhteiskunnalliset asenteet [It All Starts from Home. Civic Knowledge and Attitudes towards Society Among Finnish Youth]. Jyväskylä: Finnish Institute for Educational Research.

Lavonen, J., \& Laaksonen, S. (2009). Context of teaching and learning school science in Finland: Reflections on PISA 2006 results. Journal of Research in Science Teaching, 46(8), 922-944. http://dx.doi.org/10.1002/tea.20339

Lim, L. (2011). Beyond logic and argument analysis: Critical thinking, everyday problems and democratic deliberation in Cambridge International Examinations' Thinking Skills $\begin{array}{lllll}\text { curriculum. Journal of } & \text { Curriculum }\end{array}$ 
http://dx.doi.org/10.1080/00220272.2011.590231

Lorde, A. (1984). Sister outsider. Berkeley, CA: The Crossing Press.

Mander, J. (2012). Privatization of consciousness. Monthly Review, 64(5), 18-41.

McLaren, P. (1998). Revolutionary pedagogy in post-revolutionary times: Rethinking the political economy of critical education. Educational Theory, 48(4), 431-463.

McLaren, P. (2010). Revolutionary critical pedagogy. InterActions: UCLA Journal of Education and Information Studies, 6(2), 1-11.

McClelland, D. C. (1973). Testing for competence rather than for "intelligence". American Psychologist, 28, 1-14.

McMillan, J., \& Harriger, K. (2002). College students and deliberation: a benchmark study. Communication Education, 51(3), 237-253. http://dx.doi.org/10.1080/03634520216518

Mitra, S., \& Dangwal, R. (2010). Limits to self-organising systems of learning-the Kalikuppam experiment. British Journal of Educational Technology, 41(5), 672-688.

Määttä, K., \& Uusiautti, S. (2012). Editorial: how do the Finnish family policy and early education system support the well-being, happiness, and success of families and children? Early Child Development and Care, 182(3-4), 291-298. http://dx.doi.org/10.1080/03004430.2011.646718

Paksuniemi, M., Uusiautti, S., \& Määttä, K. (2012). Teacher education in Finland during the war years 1939-1945. War \& Society, 33(1), in press.

Paley, V. (1992). You can't say you can't play. Cambridge, MA: Harvard University Press.

Parker, W. C. (1997). The art of deliberation. Educational Leadership, 54(5), 18-21.

Rinne, R. (2000). The globalization of education: Finnish education on the doorstep of the new EU millennium. Educational Review, 52(2), 131-142

Rinne, R., Kivirauma, J., \& Simola, H. (2002). Shoots of revisionist education policy or just slow readjustment? The Finnish case of educational reconstruction. Journal of Education Policy, 17(6), 643-658.

Roine, A. (2010). Best available world: a manifesto for a new future. Helsinki Times, Issues 25 and 26.

Saevi, T., \& Eilifsen, M. (2008). 'Heartful' or 'heartless' teachers? Or should we look for the good somewhere else? Considerations of students' experience of the pedagogical good. Indo-Pacific Journal of Phenomenology, 8, 1-14.

Simola, H. (2004). Kenraali Adolf Ehrnrooth ja PISA:n ihme - Koulutussosiologisia huomautuksia erääseen suomalaiseen menestystarinaan [General Adolf Ehrnrooth and the miracle of PISA - Educational sociological notions concerning one Finnish success story]. Kasvatus, 1, 76-83. 


\section{Macrothink}

Journal of Studies in Education

ISSN 2162-6952

2013, Vol. 3, No. 2

Stringer, N. (2008). Aptitude tests versus school exams as selection tools for higher education and the case for assessing educational achievement in context. Research Papers in Education, 23(1), 53-68. http://dx.doi.org/10.1080/02671520701651771

Tyack, D. (1997). Civic education-what roles for citizens. Educational Leadership, 54(5), $22-24$.

Välijärvi, J., Kupari, P., Linnakylä, P., Reinikainen, P., Sulkunen, S., Törnroos, J., \& Arffman, I. (2007). The Finnish success in PISA - and some reasons behind it 2. PISA 2003. Jyväskylä: Institute for Educational Research.

Webb, R., Vulliamy, G., Hämäläinen, S., Sarja, A., Kimonen, E., \& Nevalainen, R. (2004). A comparative analysis of primary teacher professionalism in England and Finland. Comparative Education, 40(1), 83-107. http://dx.doi.org/10.1080/0305006042000184890

West, C. (2004). Democracy matters: winning the fight against imperialism. New York, NY: Penguin Press.

Wilkerson, K. (2011). Flying close to the sun. New York, NY: Seven Stories Press.

Zembylas, M., \& Michaelides, P. (2004). The sound of silence in pedagogy. Educational Theory, 54(2), 193-210. http://dx.doi.org/10.1111/j.0013-2004.2004.00005.x

\section{Copyright Disclaimer}

Copyright reserved by the author(s).

This article is an open-access article distributed under the terms and conditions of the Creative Commons Attribution license (http://creativecommons.org/licenses/by/3.0/). 